A N N A L ES

UNIVERSITATIS MARIAE CURIE-SKŁODOWSKA

LUBLIN - POLONIA

VOL. LXVI, 1

SECTIO G

2019

Elbląska Uczelnia Humanistyczno-Ekonomiczna

ANDRZEJ SYLWESTRZAK

a.sylwestrzak@wp.p1

ORCID: 0000-0002-3707-9598

\title{
Doktryna chrześcijańskiego małżeństwa w De bono coniugali na tle metodologii św. Augustyna
}

The Doctrine of Christian Marriage in De bono coniugali against the Background of St. Augustine's Methodology

Aureliusz Augustyn (354-430) urodził się w północnoafrykańskim mieście Tagasta i bywa nazywany Augustynem z Tagasty. W czasie burzliwej młodości pozostawał pod wpływem neoplatonizmu i epikureizmu, należał bowiem do religijnej sekty manichejczyków. W Tagaście i Kartaginie nauczał gramatyki i retoryki; kontynuując studia, udał się do Mediolanu. Tu zbliżył się do gmin chrześcijańskich - poznał i przyjął ich wiarę i naukę. W 387 r. otrzymał chrzest, a w $391 \mathrm{r}$. przyjął święcenia kapłańskie, po czym powrócił do Afryki. Osiadł w Hipponie, gdzie został biskupem. Obserwował stąd zagrożenie Cesarstwa Zachodniego wraz z zajęciem w 410 r. Rzymu przez Gotów pod wodzą Alaryka. To wstrząsające wydarzenie dowodziło rychłego załamania się potęgi stabilizującej imperialny porządek i było przyczyną ataków na chrześcijan oskarżanych o osłabianie Rzymu. Rozważając te obawy, Augustyn napisał w latach 410-430 dwudziestodwutomowy traktat o charakterze historiozoficzno-teologicznym zatytułowany Państwo Boże (De civitate Dei), w którym zamieścił wykład dialektyki rozwoju świata ${ }^{1}$. Warto zaznaczyć, iż pisarstwo Augustyna jest wyjątkowo bogate zarówno w formy, jak i podejmowane problemy. Z tego jednak wynikają poważne trudności związane z jednoznacznym odczytaniem jego fundamentalnych idei, budzących znaczne rozbieżności interpretacyjne. $Z$ punktu widzenia doktryn politycznych postać św. Augustyna przedstawia się jako swoiste podsumowanie nie tylko myśli

1 Św. Augustyn, Państwo Boże, Kęty 1998. Zob. idem, Wyznania, Warszawa 1989, s. 344-357. 
wczesnochrześcijańskiej, lecz także filozofii politycznej starożytności, otwierając perspektywy związane z zarysowaniem epoki wczesnofeudalnej².

$\mathrm{Na}$ tym tle umiejscowienie rozprawy pt. Wartości matzeństwa ma liczące się znaczenie metodologiczne ${ }^{3}$. Znawcy pisarstwa św. Augustyna nie mają wątpliwości, iż powstało ono w latach 400-401, tym bardziej że zostało napisane $\mathrm{z}$ jednej strony $\mathrm{w}$ ostrej polemice $\mathrm{z}$ popularnym szczególnie w Afryce manicheizmem, a $\mathrm{z}$ drugiej w atmosferze potępienia doktryny Jowiniana. Obie szkoły zwalczał ówczesny papież Syrycjusz, który odrzucił je na Synodzie rzymskim (około 390 r.). Także następny papież - Anastazy (pontyfikat w latach 399-401) - włączył się do dyskusji, a tą kwestią krytycznie zajęli się dwaj Święci Doktorzy Kościoła: Ambroży i Hieronim, co w sumie nadało sprawie fundamentalne dla chrześcijaństwa znaczenie. Później św. Augustyn wielokrotnie do niej powracał, m.in. w napisanym w 419 r. De nuptiis et concupiis, a następnie w De Santa Virginitate; ponadto podjął polemikę z biskupem Pelagiuszem. Głównie szło o potępienie małżeństwa przez manichejczyków, lecz także o zrównanie przez Jowiniana małżeństwa ze stanem duchownym ${ }^{4}$. W tej sytuacji św. Augustyn uznał, iż należy przedstawić pełniejszy wykład chrześcijańskiej filozofii małżeństwa do tego problemu powracał przez cały okres swego pisarstwa, w szczególności w wielu miejscach traktatu Państwo Boże.

W niniejszym opracowaniu treść rozprawy Wartości matżenstwa zostanie przedstawiona $\mathrm{w}$ konfrontacji z głównymi przesłankami metodologii augustiańskiej, dzięki czemu można będzie ocenić ogólniejszą spójność badawczą tej pracy na tle dialektyki zaprezentowanej w Państwie Bożym. Otóż podstawowym przesłaniem rozprawy Wartości malżeństwa okazuje się wyeksponowanie jego trzech głównych celów. Są to: a) zrodzenie i wychowanie potomstwa; b) wzajemna wierność małżonków; c) świętość samego sakramentu. Ponadto założeniem głównym jest „dobro samo w sobie” małżeństwa, także w sensie walki z rozpustą, chociaż małżeństwo nie jest dobrem koniecznym. Między tymi trzema celami głównymi małżeństwa nie ma równorzędności. Mianowicie w sytuacji braku potomstwa aktualne są dwa pozostałe, a element trzeci - oparty na „świętości małżeństwa” - został umiejscowiony na najwyższym miejscu.

„Dobro” małżeństwa opiera się na założeniu, iż staje się ono główną sferą społecznego bytowania człowieka, również w sensie budowy warstw czy klas społecznych, zawsze znajdujących fundament w społeczności rodzinnej. W tym sensie rodzina staje się podstawową komórką kultywowania „miłości chrześcijańskiej” (Caritas Christiana), dając wyraz nie tylko jej idealistycznemu pojmo-

2 Zob. P. Brown, Augustyn z Hippony, Warszawa 1993.

3 Św. Augustyn, Wartości matżeństwa, Pelplin 1980.

$4 \quad$ W polemice z Jowinianem św. Augustyn napisał rozprawkę Przeciw Jowinianowi, a jej tezy pogłębił w traktacie Wartości wdowieństwa oraz napisanym w 419 r. antypelagiańskim liście De nuptiis et concupiscentia, tj. O malżeństwie i pożąlliwości. 
waniu, ale też służąc w najlepszy sposób zbiorowości. Tym samym małżeństwo zostaje przeciwstawione innym formom współżycia, zwłaszcza konkubinatowi, ponieważ nawet dążenie do urodzenia potomstwa nie usprawiedliwia konkubinatu ${ }^{5}$. Wprawdzie cel główny małżeństwa, polegający na prokreacji, staje się założeniem podstawowym, jednak niepłodność nie usprawiedliwia jego rozwiązania. Co więcej, małżonkowie pragnący potomstwa nie powinni przy swojej bezpłodności wchodzić w inne związki, w tym działając z pobudek rodzicielskich, ponieważ wówczas dopuszczają się cudzołóstwa ${ }^{6}$. Nakaz ten jest bardzo wyrazisty, ponieważ św. Augustyn pisze: „Jak lepiej jest umrzeć z głodu, niż żywić się pokarmem bogom ofiarowanym, niż zrodzić potomstwo z niedozwolonych stosunków"'. W Państwie Bożym Augustyn około 420 r. najbardziej dosadnie sformułował swoje stanowisko: „Związek więc mężczyzny z kobietą jest, gdy chodzi o ród śmiertelny, jak gdyby rozsadnikiem państwa"8. Augustyn spotkał się z problemem wielożeństwa, które w wyjątkowych wypadkach ze względów prokreacyjnych dopuszczał jako poligamię, zdecydowanie odrzucając poliandrię. Natomiast niepłodność nie usprawiedliwia rozwiązania małżeństwa, ponieważ z jego istoty wynika trwałość związku, aż do śmierci jednej ze stron ${ }^{9}$. Nawiązanie trwałego związku w tej sytuacji z inną osobą jest po prostu cudzołóstwem.

Drugim podstawowym celem małżeństwa jest utrzymanie silnych więzi emocjonalnych, opartych głównie na poszanowaniu wierności. Św. Augustyn nie przeciwstawia sobie pojęcia celów i wartości małżeństwa. Trzy główne cele małżeństwa w praktyce opierają się na wartościach, dla których małżeństwo w ogóle funkcjonuje ${ }^{10}$. O ile małżeństwo skonstruowane według tych kryteriów jest

5 Św. Augustyn (Wartości..., s. 68) wskazuje: „XIV.16. Przeto zróbmy przypuszczenie, które nie wiem, czy jest możliwe, czy raczej sądzę, jest niemożliwe. Gdyby konkubina na pewien czas wzięta pragnęła ze współżycia tylko mieć dzieci, to nie wolno takiego związku przedkładać nad małżeństwo".

6 Św. Augustyn (ibidem, s. 69) podkreśla: „Bo trwa związek małżeński, choćby na skutek jawnej niepłodności nie było potomstwa, dla którego małżeństwo zawarli. Wobec tego nie wolno małżonkom, choćby wiedzieli, że nie będą mieli dzieci, z tego powodu rozejść się i wejść w inne związki. A jeśliby się tego dopuścili, to popełniając cudzołóstwo z tymi, z którymi się związali, mimo to pozostają małżonkami”. Augustyn rozważaniom nad cudzołóstwem poświęcił osobny wykład De coniugiis adulterinis (Związki cudzołożne), pozostający w zgodzie z ustaleniami zawartymi w Wartościach matżeństwa.

7 Ibidem, s. 70-71.

8 Idem, Państwo..., t. 2, rozdział 17, s. 192.

9 Św. Augustyn (Wartości ..., s. 69) podaje: „Wobec tego nie wolno małżonkom, choćby wiedzieli, że nie będą mieli dzieci, z tego powodu rozejść się i wejść w inne związki. A jeśliby się tego dopuścili, to popełniają cudzołóstwo z tymi, z którymi się związali”"

10 W. Eborowicz (Wstęp, [w:] Św. Augustyn, Wartości ..., s. 20) akcentuje: „Dlatego nie widzimy u samego Augustyna rzeczowej różnicy między celem a dobrem. Mimo to wolno się doszukiwać wartości będącej źródłem pozostałych. Jest nią siła przyjaźni, którą uwydatniają i nastawienie ascetyczne Biskupa Hippony, i tzw. jego eschatalogizm, a nawet nauka Świętego o przeznaczeniu". 
filozoficznym wzorcem, o tyle jego przeciwieństwa w postaci cudzołóstwa dowodzą degradacji samej instytucji. Wartość monogamicznego małżeństwa również sprowadza się do uporządkowania każdej społeczności. Jeśli chrześcijańskie małżeństwo stanowi wzorzec porządku i harmonii, to jego zaprzeczenie (głównie w formie cudzołóstwa) odpowiada anarchii wraz ze wszystkimi jej destrukcyjnymi następstwami. Cudzołóstwo i rozpusta okazują się „grzechami śmiertelnymi”, siłą rzeczy zasługującymi na potępienie. Augustyn określa z tej perspektywy małżeństwo jako „pakt wierności” i w tym sensie traktuje wierność jako - zdaniem Wacława Eborowicza - „wartość, którą należy stawiać wyżej niż zdrowie ciała, a nawet życie"l1.

Na tym tle Augustyn rozważa sytuację „związku osób stanu wolnego”, opartego na długotrwałości i wierności obu stron, nie wykluczając zrodzenia potomstwa. Dochodzi jednak do przekonania, iż nie można zdecydowanie go potępić, nazywając cudzołóstwem, chociaż z pewnością nie daje się zrównać z małżeństwem. Problem powstaje, gdy żona, mająca męża dopuszczającego się cudzołóstwa, opuszcza go i odwrotnie - gdy żona, uprawiająca cudzołóstwo, upoważnia męża do opuszczenia związku. W praktyce takie sytuacje wydają się sprawiedliwe, lecz w żadnym wypadku cudzołóstwo jednej strony nie upoważnia do usankcjonowania nowego związku małżeństwem.

Tak pojmowane małżeństwo „nie jest tylko wartością względną”. Okazuje się ono wartością bezwzględną, tzn. obowiązującą wszystkich członków społeczeństwa i państwa. Procedury nadające małżeństwu formę instytucjonalną tylko potwierdzają bezwzględny charakter samej instytucji. Na tym tle powstaje problem małżeństw mieszanych, zawartych między stroną chrześcijańską i niechrześcijańską. Tutaj Augustyn nie zajmuje zdecydowanego stanowiska, lecz powołuje się na apostoła Pawła: „Uświęcony jest bowiem mąż niechrześcijanin przez żonę chrześcijankę i uświęcona jest żona niechrześcijanka przez męża chrześcijanina"12. W tej sytuacji wydaje się, iż taki związek posiada cechy małżeństwa, co wskazuje raczej na interpretację rozszerzającą rygorystyczne pojmowanie samej instytucji.

Trzecim celem małżeństwa jest funkcja eschatologiczna, polegająca na pojmowaniu go jako sakramentu. W zasadzie, biorąc pod uwagę postawę wyznaniową św. Augustyna, ten trzeci cel zdaje się najważniejszy, ponieważ łączy małżeństwo bezpośrednio z prawem Bożym. Dwa pozostałe cele ( $\mathrm{tj}$. prokreacja i więzi emocjonalne, oparte na wierności) wynikają z tego trzeciego celu. Po prostu boskość małżeństwa przesądza o jego treści, a więc pojmowanie małżeństwa w sensie jego nierozerwalności jest konsekwencją sakramentu samej instytucji. Małżeństwo posiada zatem (jako podstawowe) cechy sakralne, a jego instytucjonalizacja prawna i uznanie przez państwo są pochodną, a więc właściwością wtórną. Niedopusz-

11 Ibidem, s. 55.

12 Św. Augustyn, Wartości..., s. 66. 
czalność rozwodu wynika wobec tego z samej sakralności związku. „Rozwód nie rozrywa - podkreśla św. Augustyn - związku małżeńskiego tak, że rozwiedzeni pozostają małżonkami, dopuszczając się cudzołóstwa z tymi, z którymi współżyją po swym rozejściu" ${ }^{\prime 3}$.

W sensie filozoficznym sakrament małżeństwa łączy małżonków z Bogiem, nadając mu wyższy (czyli mistyczny) sens. W rezultacie dzieci będące „naturalnym owocem” tak interpretowanego małżeństwa są „dziełem Bożym”. „Bóg ustanowił małżeństwo, aby w uporządkowany i uczciwy sposób rodziło dzieci" "14. Św. Augustyn nie ma wątpliwości, iż małżeństwo, stanowiąc najwyższą formę związku społecznego, jest formą niższą względem stanu kapłańskiego. Ten bowiem w świetle prawa Bożego stanowi najwyższą postać funkcjonowania człowieka, chociaż nie pozostaje w żadnych relacjach względem trzech funkcji przypisanych małżeństwu. Zadaniem stanu kapłańskiego jest uświadamianie człowiekowi jego praw i obowiązków (także w zakresie małżeństwa) oraz procedowanie samego sakramentu jego zawarcia. W tych właśnie kategoriach św. Augustyn pojmuje także własną rolę jako kapłana i biskupa, a dopiero w drugiej kolejności - jako filozofa pracującego nad doktryną małżeństwa.

Zarysowana $\mathrm{w}$ ten sposób chrześcijańska teoria małżeństwa zostanie przedstawiona na tle ogólniej pojętej metodologii myślenia augustiańskiego. Sprawa wydaje się jednak o tyle skomplikowana, iż rozprawa Wartości matżeństwa została napisana w latach 400-401, a podstawowe dzieło św. Augustyna (również $\mathrm{w}$ zakresie metodologii) powstało $\mathrm{w}$ latach $410-430^{15}$. Pewnym rozwiązaniem jest ustalenie, w myśl którego w De civitate Dei pozostawał on konsekwentny względem swych wcześniejszych prac, w wielu wypadkach pogłębiając tezy tam zaprezentowane, co dotyczy też małżeństwa ${ }^{16}$.

1. Otóż leżącą u podstaw myślenia św. Augustyna zasadę można sprowadzić do najszerzej pojętego teocentryzmu, ujmującego personalistycznie istotę Boga, w nieskończoności upatrującego Jego najwyższy przymiot. Człowiek, mając w duszy zaszczepione poczucie prawdy, szuka jej w trakcie całego swego postępowania. Poznając rzeczywistość, poznaje Boga, ponieważ świat nas otaczający jest dziełem boskim, stąd św. Augustyn nie odróżniał filozofii od teologii, traktował je w jedności wiedzy prowadzącej do Boga. Małżeństwo, będąc sakramentem, prowadzi do pojednania małżonków z Bogiem i tym samym dowodzi, iż posiada taką samą rangę, jak chrzest czy inne sakramenty.

2. W dziedzinie etyki, zrywając z greckim intelektualizmem, św. Augustyn stanął na stanowisku woluntaryzmu, który głosił, iż człowiek kształtuje swe po-

13 Ibidem, s. 60.

14 Ibidem, s. 71.

15 Idem, Państwo...

16 Por. W. Kornatowski, Społeczno-polityczna myśl św. Augustyna, Warszawa 1968, s. 12-15; A. Kasia, Święty Augustyn, Warszawa 1974, s. 45-54. 
stępowanie w rezultacie świadomie i swobodnie podejmowanych aktów woli. Samo pojęcie wolności ujmował w dwóch znaczeniach: 1) wolności formalnej; 2) wolności moralnej. Wolność formalna oznacza możliwość dokonania przez jednostkę wyboru między dobrem i złem, jest zatem szansą na swobodne kształtowanie swego postępowania. Wolność moralna posiada - z etycznego punktu widzenia - znaczenie zasadnicze, sprowadza się bowiem do wewnętrznej dyspozycji unikania zła i czynienia dobra. Jest to podstawowy rodzaj wolności - pozwala on na konstruktywny rozwój człowieka, będący zasadą postępu społecznego, moralnego czy politycznego. Wolność moralna prowadzi do obcowania człowieka z Bogiem, do ciągłego zbliżania się do Boga jako ostatecznego celu ludzkiego życia. W najwyższym niejako stopniu pogłębiania tej wolności człowiek może zbliżyć się do poznania „niemożności grzeszenia” (non posse pecare). Małżeństwo chrześcijańskie dowodzi istnienia obu tych wolności, ponieważ jest związkiem dobrowolnym, a poszanowanie jego zasad oznacza realizację wolności moralnej. Założenia te nie oznaczają, iż św. Augustyn reprezentował optymistyczną wizję świata coraz bardziej się doskonalącego. Wręcz odwrotnie, jest to raczej wizja pesymistyczna, pozwalająca dostrzec, jak wiele zła nadal istnieje w stosunkach miedzyludzkich, w tym w małżeństwie. Cnota wolności moralnej, przy oświecającym wpływie „łask boskich”, prowadzi do poznania dobra. Reszta przypomina środowisko drapieżnych zwierząt, pożerających się nawzajem. Ten fatalizm został wyprowadzony także z pesymistycznych ocen możliwości przetrwania imperium rzymskiego i rysującej się dramatycznej wizji załamania ówczesnego porządku wraz z przewidywanym ewangelicznym końcem świata.

3. Metodologia dwóch państw staje się zasadą swoistej dialektyki św. Augustyna. Zdobycie w 410 r. Wiecznego Miasta przez wojska Alaryka, a także szerzenie się poglądu, iż jest to rezultat odejścia od wiary przodków, stawianie za przykład pozostałych jeszcze w pamięci rządów Juliana Apostaty urastało do rangi generalnego oskarżenia chrześcijaństwa. Augustyn podją tę problematykę, biorąc pod uwagę to, że ocena przeszłości daje również szansę spojrzenia w przyszłość. Rozważaniom tym poświęcił dzieło De civitate Dei, w którym zasadą thumaczenia biegu wypadków jest walka między „państwem Bożym” (civitas Dei) a „państwem ziemskim” (civitas terrena). „Państwo Boże” to symbol dobroci, przebaczenia i miłości jako wartości podstawowych w etyce chrześcijańskiej. Przeciwieństwem jest „państwo ziemskie” (zwane niekiedy „państwem szatana”), będące siedliskiem grzechu, zła i nienawiści, słowem - szeroko pojętej destrukcji. „Państwo Boże” rozwija się pod znakiem Chrystusa, natomiast ,państwo ziemskie” należy do szatana. Bieg historii to wojna między tymi państwami. Ich dotychczasowy rozwój św. Augustyn przedstawia w stadialnych epokach, gdzie układ sił przybierał różne postaci, by w przyszłości doprowadzić do ostatecznego zwycięstwa 
państwa Chrystusowego, a więc triumfu dobra nad złem. W De civitate Dei św. Augustyn wielokrotnie nawiązuje do instytucji małżeństwa, ujmując ją w świetle swej metodologii. Otóż małżeństwo chrześcijańskie, spełniające wszystkie wymogi, jest wyrazem „państwa Bożego”. Natomiast występująca patologia czy destrukcja dowodzą przewag ,państwa ziemskiego” i nie ma tutaj stabilności. Dialektyka polega na ciągłym zagrożeniu chrześcijańskiego porządku przez destrukcję, co zobowiązuje człowieka do nieustannego analizowania prawidłowości swego postępowania.

4. Małżeństwo można oceniać także w świetle Augustiańskiej nauki o cnotach. Idąc śladem Platona i Cycerona, św. Augustyn wyróżnił wiele cnót, a wśród nich cztery cnoty kardynalne: sprawiedliwość, roztropność, męstwo i umiarkowanie. Zgodnie z filozofią chrześcijańską traktował je łącznie jako pochodne „miłości”, będące jej częściami czy szczególniejszymi objawami. Otóż sprawiedliwość jest miłością służącą wyłącznie rozstrzyganiu spraw konfliktowych. Roztropność okazuje się miłością w umiejętności rozwiązywania problemów polegających na niesieniu człowiekowi pomocy. Męstwo to miłość przezwyciężania trudności piętrzących się przed wyznaczonym sobie celem. Wreszcie umiarkowanie jest miłością oddawania się celowi miłości wraz z umiejętnością ponoszenia wyrzeczeń. Chrześcijańsko pojęta miłość (caritas christiana) staje się więc przyczyną sprawczą doskonalenia człowieka, stanowiąc konieczną przesłankę rozwoju jednostkowego oraz zbiorowego. W tym świetle św. Augustyn ocenia małżeństwo jako urzeczywistniany w jedności katalog cnót i różnych postaci miłości, chociaż przesłanką do jego osiągnięcia jest stan małżeństwa chrześcijańskiego.

5. Małżeństwo jest instytucją sprawiedliwą, pozostającą w związku z ogólniejszą filozofią sprawiedliwości św. Augustyna. Mianowicie sprawiedliwość, będąc jedną z cnót kardynalnych, wysuwa się na czoło (obok miłości) ontologicznych atrybutów moralnego funkcjonowania jednostki. Św. Augustyn ujmuje sprawiedliwość w kilku znaczeniach, a najważniejsze z nich to: sprawiedliwość boska, sprawiedliwość aksjologiczna, sprawiedliwość społeczna i sprawiedliwość prawna. Najogólniej mówiąc, sprawiedliwość okazuje się „sprawnością”, czyli rodzajem wyższej kultury człowieka. Sprowadza się ona zasadniczo do poczucia oddania każdemu tego, co słusznie mu się należy - jest więc postawą świadczenia i korzystania w jedności. Sprawiedliwość powinna być wsparta miłością, inaczej się degraduje. W tym sensie jest formą świadomości człowieka, aczkolwiek prawzorcem pozostaje sprawiedliwość boska, również oparta na miłości boskiej jako idealnej harmonii Deus caritas est („Bóg jest miłością”), a z tego wynikają inne postaci doskonałości, w tym sprawiedliwości.

6. Zarówno w sensie metodologicznym, jak i ontologicznym „sprawiedliwość Boża” jest wiedzą najwyższą (summa sapientia) i powszechną (summa 
universalis). Pojęcia te św. Augustyn wyprowadził wprawdzie z filozofii stoicko-cycerońskiej, napełnił je jednak treściami chrześcijańskimi i uzyskał rezultat boskiej sprawiedliwości doskonałej, wyznaczającej granice jej pozostałym postaciom. Metodologicznie zatem „bezwzględność” sprawiedliwości boskiej czyni pozostałe stopnie sprawiedliwości ,względnymi" tak samo, jak jej doskonałość pozwala w innych wypadkach traktować jedynie o stopniach określonej niedoskonałości. Ten platoński idealizm został podbudowany dialektyką sprawiedliwości jako treściowego kryterium „państwa Bożego”. Dialektyka tych pojęć, również w filozofii państwa, wyznacza kryteria rozwoju cywilizacji. Metodologicznie sprawiedliwość opiera się z jednej strony na jej dialektycznej interpretacji w konfrontacji z różnymi postaciami niesprawiedliwości, z drugiej zaś na transcendentnym pojmowaniu „sprawiedliwości bezwzględnej”, wyznaczając wzorce najwyższej doskonałości. Sprawiedliwość w sensie „aksjologicznym” bierze za przedmiot katalog wspomnianych cnót fundamentalnych, wyznaczających zasady i cele postępowania człowieka, tj. roztropność, męstwo, umiarkowanie (w tym sensie także sprawiedliwość). Poszczególne definicje tych cnót mają sens przy założeniu ich zdynamizowania przez „miłość chrześcijańską", prowadzącą do finalnego połączenia z Bogiem. W innych wypadkach powyższa aksjologia staje się jedynie „doczesnym” i „względnym” systemem wartości. Chodzi bowiem o podkreślenie, w perspektywie filozofii chrześcijańskiej, wyższych społecznie i mistycznie cech przyjętych założeń. Bez tego kryterium „cnoty” społeczne czy polityczne mogą funkcjonować również $\mathrm{w}$ świecie pogańskim, jak miało to miejsce w starożytnych Atenach czy Rzymie. Filozofia chrześcijańska nadaje przyjętej aksjologii postać mistyczną, zbliżającą ją do Boga. Instytucja małżeństwa całkowicie wpisuje się w tak definiowaną sprawiedliwość, a poprzez jego sakramentalność łączy się z boską ideą sprawiedliwości. Społeczne znaczenie sprawiedliwego małżeństwa sprowadza się do umiejętności harmonijnego kształtowania zachowań zintegrowanych jednostek, zmierzających do urzeczywistniania wspólnych celów. Chodzi o dobro powszechne, a sprawiedliwość znajduje wyraz w konstruktywnym korzystaniu z wolności, pokoju i pracy. Zasadą rozumowania św. Augustyna jest wyznaczenie podstawowych celów zbiorowości przy założeniu, że składa się ona z jednostek uformowanych na podstawie przyjętej aksjologii. Punktem wyjścia tej odmiany sprawiedliwości jest wolność. Stanowi ona wprawdzie osobny problem, lecz nie ulega wątpliwości, iż pozostaje zasadą powszechnej sprawiedliwości. Otóż wolność zarówno w sensie politycznym, jak i moralnym jest podstawą sensownego traktowania wszystkich aspektów sprawiedliwości społecznej. Warto przytoczyć znane zdanie z De civitate Dei: „Stąd człowiek prawy, chociażby był niewolnikiem, jest wolny; niegodziwiec 
zaś, choćby znajdował się na tronie, jest niewolnikiem, i to nie jednego człowieka, lecz - co gorsza - tylu panów, ile ma w sobie wad" ${ }^{17}$. Jedynie człowiek wolny i moralnie odpowiedzialny za swą wolność może być sprawiedliwy. Bez tej konstrukcji nie jest możliwe harmonijne bytowanie jednostki. „Co prawda, jeśli się lepiej zastanowić, tylko człowiek szczęśliwy żyje tak, jak chce, a nikt nie jest szczęśliwy, jeśli nie jest sprawiedliwy"18. Rozumne korzystanie z wolności, przez podbudowanie jej treściami bezpośrednio wynikającymi z przyjętego katalogu aksjologicznego, wyznacza więc podstawowe granice i sens sprawiedliwości społecznej.

7. Sprawiedliwość w sensie „prawnym” leży u źródeł wspólnego porządku, państwo zaś, będąc związkiem ludu (res populi), ustanawia zasady społecznej i władczej organizacji, czego wyrazem jest prawo. Pełniejszą definicję państwa św. Augustyn przytacza w De civitate Dei, twierdząc, iż ,lud jest wielką rozumną gromadą, zespoloną przez zgodną jedność w umiłowanych przez się sprawach" ". Sprawiedliwość, będąc przede wszystkim wartością etyczną, pozostaje w bezpośrednich związkach z innymi cnotami, w zasadniczy sposób kształtując moralny rozwój człowieka, małżeństwa i państwa. To ostatnie, jako zrzeszenie rozsądnie działających jednostek, powinno urzeczywistniać zadania finalnie odpowiadające dobru jednostki. Augustyn zdaje sobie sprawę, iż w praktyce bywa inaczej, co oznacza pogwałcenie harmonizującej całość idei sprawiedliwości. Gwarantowany przez państwo porządek okazuje się pokojem, a ten daje wyraz sprawiedliwości w organizacji życia tak jednostki, jak i państwa i społeczności międzynarodowej. Idea „spokoju porządku” (tranquilitas ordinis), wyłożona na kartach De civitate $D e i$, sprowadza się do uzasadnienia konieczności ustanowienia racjonalnych wzorców odpowiadających boskiemu posłannictwu człowieka, w tym sensie dając wyraz sprawiedliwości prawnej jako sprawiedliwości ludzkiej. Instytucja małżeństwa doskonale wpisuje się w te aspekty Augustiańskiej wolności i sprawiedliwości ${ }^{20}$.

8. Idea pokoju okazuje się fundamentalną zasadą organizacji państwa w stosunkach wewnętrznych oraz polityce zagranicznej. W polityce wewnętrznej państwo powinno urzeczywistniać trzy cele podstawowe: porządek, jedność i pokój. Pokój wewnętrzny promieniuje na zewnątrz, aczkolwiek elementarną cząstką pokoju jest osobowość człowieka. Należy ustanowić pokój we własnym sumieniu, a więc „zabić wojnę” (morte bella) w świecie własnej osobowości, by tym skuteczniej mówić o pokoju wewnętrznym

17 Św. Augustyn, Państwo..., t. 2, księga IV.

18 Ibidem, t. 2, księga XVI, 24, 2.

19 Ibidem, t. 2, księga XIX, 25, 2.

20 Zob. idem, Doskonała sprawiedliwość człowieka, Pelplin 1982, s. 76-98. 
i zewnętrznym. Tym samym pokój staje się podstawowym kryterium funkcjonowania małżeństwa i rodziny. Późniejsza tomistyczna teoria harmonii bierze za podstawę Augustiańską doktrynę pokoju, oznaczającą w odniesieniu do małżeństwa wykluczenie wojny, czyli wszystkich form jego degeneracji ${ }^{21}$.

9. Teoria prawa św. Augustyna opiera się na założeniu mówiącym o konieczności posiadania przez państwo instrumentów umożliwiających osiąganie stojących przed nim zadań. Podstawowe okazuje się prawo pisane, gwarantowane władzą państwa, które może względem opornych stosować kary. Ludzkie pojmowanie sprawiedliwości jest jednak wysoce niedoskonałe w porównaniu z najwyższą sprawiedliwością boską. Św. Augustyn zatem dochodzi do teorii źródeł prawa pisanego, znajdującego swe podstawy w prawie boskim, wyróżniając dalej prawo naturalne oraz prawo doczesne. Taka jest hierarchia źródeł prawa, gdzie fundamentalną rolę spełnia „prawo boskie" (lex aeterna, lex Dei, lex divina), do którego zasad nawiązuje „prawo naturalne" (lex naturalis), a dopiero na trzecim miejscu jest „prawo doczesne", czyli ustanowione przez państwo (lex temporalis). Prawo boskie charakteryzuje się ponadczasowością i oznacza doskonałość. „Jest to prawo, według którego sprawiedliwość jest równoznaczna z powszechnym panowaniem idealnego ładu". Zawiera ono najwyższą wiedzę (summa sapientia) i powszechną mądrość (sapientia universalis). Człowiek rozsądny, pogłębiający cnoty chrześcijańskie, stosuje w praktyce tylko zasady prawa Bożego, a te w zupełności wystarczają do prowadzenia życia godziwego i pojednania $z$ Bogiem. Prawo natury zajmuje drugie miejsce, zostało bowiem wpisane przez Opatrzność w duszę ludzką. Człowiek z chwilą osiągnięcia wieku rozumnego odkrywa w swej osobowości katalog praw podstawowych, do których urzeczywistnienia dąży. Są to prawa niezbędne do życia i rozumnego rozwoju. Prawo natury jest wspólne dla wszystkich narodów, a jego wzorcem jest w zarysie rzymskie pojęcie ius gentium, nawiązujące do moralnych nakazów Starego Testamentu. Ustanowione prawo doczesne (lex temporalis) zbliża się do rzymskiego pojęcia iuris civilis, nie zawiera jednak zasad idealnej sprawiedliwości; zmienia się ono dość często. Z punktu widzenia mocy obowiązującej jest zlokalizowane miejscowo i czasowo oraz charakteryzuje się gwarancjami przymusu państwowego. Prawo Boże i prawo natury nie posiadają takich sankcji i są stosowane dobrowolnie - służąc sprawiedliwości wyższej, prowadzą człowieka do zbawienia. Małżeństwo występuje w tych wszystkich porządkach prawnych, dowodząc konieczności poszanowania jego zasad przez konstruktywnie działającego człowieka. W tym zakresie św. Augustyn przygotował prere-

21 Por. idem, Rozum i wiara, Warszawa 1993, s. 49-53. 
nesansową teorię św. Tomasza z Akwinu, wyraźnie uświadamiając granice między prawem a moralnością ${ }^{22}$.

10. Z hierarchicznego pojmowania źródeł prawa św. Augustyn wyprowadził wnioski nader dalekie. Należy stosować prawo doczesne, ponieważ pozostaje gwarancją pokoju i bezpieczeństwa, chociaż w wypadku sprzeczności między normą prawa doczesnego a prawem boskim bezwzględnie należy stosować prawo boskie. Teoria ta podbudowuje średniowieczne pojęcie ,,prawa oporu" (ius opportunitas), w tym wypadku względem wszelkich zaleceń wbrew chrześcijańskiemu pojmowaniu małżeństwa. W ten sposób św. Augustyn pokonuje to stadium rozwojowe, zmierzając w kierunku późniejszych teorii indywidualistycznych. Prawo Boże i prawo natury zawierają katalog zasad nie tyle oceny sensowności istnienia konkretnej formacji politycznej, ile przede wszystkim obrony jednostki wraz z gwarancjami jej bezpieczeństwa, a w konsekwencji bezpieczeństwa i rozwoju zbiorowości. Tym samym chrześcijańskie małżeństwo okazuje się gwarantem bezpiecznego i harmonijnego funkcjonowania jednostki²3.

Nauka społeczna św. Augustyna opiera się na poszanowaniu godności i równości człowieka, czyli fundamentalnych wartości w organizacji państwa. Z tego punktu widzenia rozwijał też koncepcje własności i wspólnoty, wolności i równości, potępienia niewolnictwa czy roli pracy i użyteczności zawodów. Głosząc miłość i chrześcijańsko pojętą pokorę, św. Augustyn był zwolennikiem wspólnoty dóbr na wzór organizacji pierwszych gmin chrześcijańskich. Własność prywatna rozbudza indywidualne pragnienia bogactwa i luksusu, tłumiąc najważniejsze wartości duszy ludzkiej i zaciemniając kryteria podstawowych kierunków aktywności człowieka. Dążąc do powiększenia własności, człowiek może wyrządzić wiele złego, a przy tym może utracić cel podstawowy, tj. zjednoczenie z Bogiem. Ideałem byłoby wyrzeczenie się własności i - podobnie jak pierwsi chrześcijanie - wspólne wytwarzanie i spożywanie dóbr, zwłaszcza że własność nie wynika z prawa Bożego, lecz z prawa doczesnego. Augustyn jednak zdaje sobie sprawę z tego, iż w rezultacie ułomności natury ludzkiej własność indywidualna w znacznym stopniu porządkuje stosunki społeczne, dlatego należy godzić się z jej utrzymaniem, mając przy tym na uwadze postulat możliwie szerokiego jej społecznego wykorzystania. Idea równości prowadzi do uznania powszechności pracy, wiążącej się z potępieniem nieróbstwa i wyzysku pracy (w szczególności niewolniczej). Praca dowodzi godności i przydatności człowieka, bogactwo zaś nie zwalnia z obowiązku pracy, lecz raczej zachęca do większego wysiłku²4.

\footnotetext{
22 Zob. ibidem, s. 112-154.

23 Zob. idem, O nauce chrześcijańskiej, Warszawa 1989, s. 49-54.

24 Zob. idem, Dialogi filozoficzne, Warszawa 1953, s. 46-53.
} 
Ustalenia te św. Augustyn przenosi na potępienie niewolnictwa, będącego zaprzeczeniem zarówno godności, równości, jak i powszechności pracy. Zdecydowanie odrzuca Arystotelesowski pogląd, iż niewolnictwo stworzyła sama natura. Wręcz odwrotnie, natura uczyniła wszystkich wolnymi i równymi, a grzech, ułomność i zaślepienie w zdobywaniu bogactw i kultywowaniu egoizmu poniżyły człowieka, sprowadzając go do roli niewolnika. Niewolnictwo zrodziło się bowiem z grzechu i należy do „państwa szatana”. Grzeszny jest człowiek, lecz przez niewolnictwo godność ludzka doznaje upokorzenia i poniżenia. Biorąc pod uwagę to, że zniesienie niewolnictwa nie było wówczas możliwe, postulował odwołanie się przynajmniej do minimum takich środków, jak: wyzwalanie, ludzkie traktowanie czy przyjmowanie niewolników do rodzin. Człowiek zawsze powinien pamiętać, iż niewolnictwo symbolizuje jego własną niewolę w okowach grzechu, nienawiści, fałszu i obłudy.

Na tym tle szczególną rolę odgrywa połączona silnymi więzami emocjonalnymi rodzina, w strukturze nawiązująca do starotestamentowego patriarchalizmu. Odpowiada ona prawu natury oraz prawu Bożemu, stanowiąc podstawę kolejnych form organizacji politycznej. Władza państwowa opiera się na rodzinie, znajduje zatem w najgłębszych przyczynach podstawę swego istnienia w prawie Bożym. Podobnie jak władza ojca w praźródłach opiera się na woli Bożej, tak samo władza państwowa nawiązuje do woli Bożej. Stąd św. Augustyn przyjmuje formułę zaczerpniętą od św. Pawła z Tarsu - non est potestas nisi ac Deo.

Małżeństwo, poprzez zgodność z prawem pisanym i swą postać sakramentalną, okazuje się instytucją łączącą prawo doczesne z prawem boskim i w tym sensie stoi w centrum problemu relacji państwa do Kościoła. Rozważając zasady współdziałania państwa i Kościoła, św. Augustyn przeszedł znaczną ewolucję, szczególnie na tle zwalczania herezji ortodoksyjnie nastawionych donatystów. Wychodząc z początkowych założeń rozdziału, był przekonany, iż państwo spełnia swe zadania, jeśli zabezpiecza porządek i pokój. Natomiast do urzeczywistniania celów wyższych, a przede wszystkim prowadzenia człowieka do Boga, powołany jest Kościół. Państwo i Kościół różnią się w wielu podstawowych kwestiach, głównie naturą, celami czy trwałością instytucji i aksjologii. Zakładając, iż człowiek składa się z ciała i duszy, odpowiednio państwo odnosi się do spraw materialnych, a Kośció - do spraw duchowych. Państwo reprezentuje siłę fizyczną, podczas gdy Kościół - wartości moralne. Państwo interesuje się zewnętrznymi przejawami postępowania człowieka, Kościół zaś jego życiem wewnętrznym, czyli sumieniem. Stabilność Kościoła, opartego w swej nauce na prawach wiary, kontrastuje z labilnością państwa, które zmienia ustroje czy cele oraz motywacje polityczne. Kościół jest powszechny i zmierza do objęcia całej ludzkości oraz istnieje wszędzie tam, gdzie pojawia się człowiek ze swą wiarą, podczas gdy państwo istnieje w określonych granicach terytorialnych i obywatelskich. 
Z tych różnic wynikają oczywiste wnioski dotyczące autonomii obu instytucji, ponieważ $\mathrm{w}$ nieingerencji należy upatrywać wspólnych korzyści. Z chwilą wkraczania państwa w sprawy Kościoła lub odwrotnie „Kościół zyskuje męczenników, a państwo traci honor". Autonomia nie oznacza izolacji czy opozycji, wręcz przeciwnie - Kościół może wspomagać państwo przede wszystkim w pogłębianiu pokoju, sprawiedliwości, lojalności i miłości, a w szczególności w poszanowaniu małżeństwa. Kościół okazuje się pomocny w formowaniu postaw moralnych czy kształtowaniu wartości etycznych użytecznych w życiu jednostki i zbiorowości. Św. Augustyn dowodzi, iż Kościół obejmuje swym wpływem zarówno poddanych, jak i rządzących, przez co sprzyja ogólniejszej harmonizacji stosunków społecznych. Wykład ten prowadził do uformowania tzw. augustianizmu politycznego. Z czasem jednak - szczególnie na tle walki z herezją - św. Augustyn doszedł do przekonania, iż należałoby wykorzystać władzę do skuteczniejszych kroków w zwalczaniu herezji. Tę funkcję państwa określił jako cogite intrare (,zmuście ich”), co stanowiło konserwatywne ukierunkowanie chrześcijaństwa, uświadamiając możliwości wykorzystania państwa w thumieniu herezji. W tej płaszczyźnie państwo miało stać się pomocnikiem Kościoła w urzeczywistnianiu jego zadań.

Ta nowoczesna naówczas Augustiańska antropologia pozwalała traktować człowieka, społeczeństwo, rodzinę i państwo jako pozostające w ciągłym ruchu (a więc $\mathrm{w}$ dynamice zmian) oraz przedstawiała propozycje celów godnych osiągnięcia. Człowiek, będąc dramatycznie uwikłany w sprzeczne dążenia krzyżujące jego aktywność między prawdą a fałszem, dobrem a złem czy miłością a nienawiścią, powinien znajdować wyraźne wskazania. Tymi wyznacznikami są u św. Augustyna prawdy chrześcijańskie wyprowadzone z poznania Boga, wskazujące na konieczność walki o wolność, godność, powszechność i humanizację pracy oraz prawdę.

Augustiańska antropologia głosiła zwycięstwo nowego systemu wartości i mimo nader wzniosłych filozoficznie i mistycznie wywodów przemawiała do ówczesnego człowieka. Kształtowała też praktykę dnia codziennego, wskazując cele wyższe, pojmowane nie zawsze w formie całkowitej abstrakcji czy bytu pojęciowego na wzór Platońskich idei, lecz jako możliwości potencjalnie tkwiące w świadomości człowieka. Był to więc system dynamicznej interpretacji świata, Augustiańska antropologia zaś wyrażała optymizm upatrujący przyszłość w ostatecznym zwycięstwie „państwa Bożego”.

Tą drogą św. Augustyn starał się formować osobowość jednostki, a następnie definiował zasady organizacji społeczeństwa i państwa. Augustiański antropocentryzm staje się wyrazem odkrywczego naówczas humanizmu, przygotowującego człowieka do przejścia przez barierę oddzielającą starą formację od nowej, przy czym optymizm biskupa z Hippony miał dodawać sił w poszukiwaniu przyszłych wzorców oraz likwidowaniu skompromitowanego niewolnictwa. 
Postać św. Augustyna zamyka okres starożytności przede wszystkim w sensie otwarcia nowych perspektyw w zakresie organizacji społeczeństwa i państwa ${ }^{25}$. Kategoryczne potępienie niewolnictwa stało się symbolem przeżycia się tej formacji i poszukiwania dróg rozwoju opartych na pracy człowieka, poszanowaniu jego godności i wartości. Tymi pojęciami św. Augustyn - poprzez potępienie niewolnictwa - zamyka niewolniczą starożytność, wyznaczając nowe kierunki myślenia, oparte na gwarancjach niepodważalnej wolności człowieka, czemu daje wyraz także małżeństwo zawarte między ludźmi wolnymi i znajdującymi w tym potwierdzenie swojej wolności. Myśl św. Augustyna - podsumowując dorobek pisarzy, w szczególności wczesnego chrześcijaństwa, jak również późnego stoicyzmu czy platonizmu i neoplatonizmu - formowała problemy nadchodzącej epoki przez krytyczne podejście do wielkich systemów starożytności, a tym samym torowała drogę nowym wzorcom organizacyjnym, politycznym i prawnym ukierunkowanym na filozofię tomizmu.

\section{BIBLIOGRAFIA}

Brown P., Augustyn z Hippony, Warszawa 1993.

Daniel-Rops H., Kościót wczesnego chrześcijaństwa, Warszawa 1969.

Eborowicz W., Wstęp, [w:] Św. Augustyn, Wartości matżeństwa, Pelplin 1980.

Gilson E., Historia filozofii chrześcijańskiej w wiekach średnich, Warszawa 1985.

Johnson P., Historia chrześcijaństwa, Gdańsk 1993.

Kasia A., Święty Augustyn, Warszawa 1974.

Kornatowski W., Społeczno-polityczna myśl św. Augustyna, Warszawa 1968.

Św. Augustyn, Dialogi filozoficzne, Warszawa 1953.

Św. Augustyn, Doskonała sprawiedliwość człowieka, Pelplin 1982.

Św. Augustyn, O nauce chrześsijańskiej, Warszawa 1989.

Św. Augustyn, Państwo Boże, Kęty 1998.

Św. Augustyn, Rozum i wiara, Warszawa 1993.

Św. Augustyn, Wartości małżeństwa, Pelplin 1980.

Św. Augustyn, Wyznania, Warszawa 1989.

\section{SUMMARY}

The article introduces the philosophical conception of "Christian marriage" worked out by St. Augustine in the treatise De bono coniugali (400-401 AD) which is a part of his polemics with the Manichaeans and Iuvinian(us). The treatise has been evaluated in the light of the Augustian methodology of De civitate Dei (410-430 AD). The author concludes that in writing De civitate Dei St. Augustine took inspiration from the methodology outlined in the earlier De bono coniugali.

Keywords: St. Augustine; teaching of the Catholic Church; marriage

25 Por. H. Daniel-Rops, Kościót wczesnego chrześcijaństwa, Warszawa 1969, s. 245-344; E. Gilson, Historia filozofii chrześcijańskiej w wiekach średnich, Warszawa 1985, s. 112-135; P. Johnson, Historia chrześcijaństwa, Gdańsk 1993, s. 55-103. 


\section{STRESZCZENIE}

W artykule przedstawiono filozoficzną konstrukcję „małżeństwa chrześcijańskiego” opracowaną przez św. Augustyna w rozprawie pt. De bono coniugali, napisanej w latach 400-401, powstałej w polemice z manichejczykami i Iuwinianem. Praca została poddana ocenie w świetle metodologii Augustiańskiej zawartej w traktacie De civitate Dei, napisanym w latach 410-430. Autor dochodzi do przekonania, iż św. Augustyn w De civitate Dei inspirował się metodologią przedstawioną w zarysie we wcześniejszym De bono coniugali.

Slowa kluczowe: św. Augustyn; nauczanie Kościoła katolickiego; małżeństwo 